\title{
COVID-19 vaccines, public health goods and Catholic social teaching: Why justice must prevail over charity in the global vaccine distribution
}

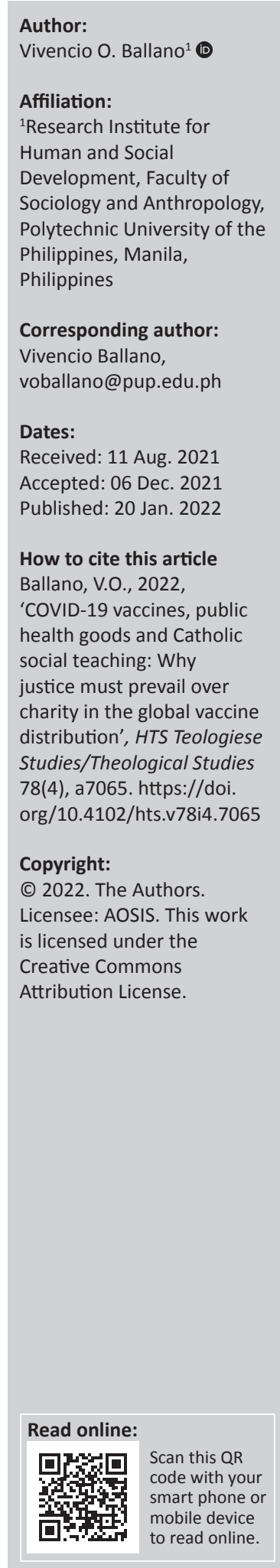

Applying the Roman Catholic Church's set of moral principles on social concerns called Catholic social teaching (CST) on charity, distributive justice, private property and the common good, and utilising some secondary data and scientific literature, this article argues that establishing distributive justice for the global distribution of the COVID-19 vaccines must be a priority than donating millions of doses in the name of charity to address vaccine scarcity. Catholic social teaching teaches that the right to private property is a basic right but has moral limits and is subordinated to the moral principles on the universal destination of earth's goods and the common good.

Contribution: The current COVID-19 vaccines are developed by people and organisations outside the pharmaceutical companies and largely funded using taxpayers' money. Thus, by virtue of justice, these vaccines must belong to all nations as global public health goods. Patents are to be suspended to allow poor countries to reproduce the popular vaccines and address the current vaccine shortage.

Keywords: COVID-19 vaccines; Catholic social teaching; distributive justice; charity; patents; big pharma.

\section{Introduction}

The announcement of the United States (US) during the recently concluded G7 Summit to donate 500 million doses of COVID-19 vaccines with an additional 870 million doses from top economies (BBC News 2021) has provided great hope for those parts of the world that continually run out of vaccines to combat the current vicious pandemic that has already killed millions of people. But this is not enough. The world needs billions of doses as fast as possible to save the poor. It requires empowering low- and middle-income countries to acquire patent rights to manufacture them locally. This donation by the US and rich G7 countries is way below the 11 billion doses the World Health Organization (WHO) estimates, which are needed to vaccinate the whole world to achieve global herd immunity if each person receives two doses. Pharmaceutical companies could not possibly manufacture enough vaccines to immunise most of the world's population by the end of 2021, given the delays and hurdles in distributing them and the hoarding of doses by wealthier countries (Irwin 2021). Top drug makers do not allow developing countries to reproduce their patented vaccines to meet this urgent global demand.

Yet, anatomising the ownership of the current popular vaccines reveals that the drug makers are not actually the absolute owners of these vaccines which are largely developed by scientists using public funds with the participation of policymakers and thousands of people in clinical trials. It is largely 'owned' morally by the public according to the Christian virtue of justice, that is, giving what is due. Thomas Cueni, the director-general of the International Federation of Pharmaceutical Manufacturers and Associations, has acknowledged that without public funds, vaccine manufacturers could not have been able to produce the current COVID-19 vaccines (Cueni 2020). Thus, one wonders: Should charity be supplanted by justice by waiving the manufacturers' patent rights to their COVID-19 vaccines in the World Trade Organization (WTO) and awarding them to local manufacturers to make them global public health goods as the right moral response to the current vaccine scarcity?

The current global shortage of vaccines has prompted India and South Africa to file a request in October 2020 in the WTO to temporarily waive the patent or ownership rights of pharmaceutical companies to their vaccines to allow poorer countries to reproduce them locally (Labonte \& Johri 
2020). Although this request is only temporary, the consortium of world's largest and most influential drug companies that constitutes Pharmaceutical Research and Manufacturers of America (PhRMA), immediately dismissed it as an empty promise that will further weaken the strained supply chains and result in counterfeit vaccines (PhRMA 2021). This request was doomed at the beginning as high-income countries that include the US, European Union (EU), Switzerland and Japan, have joined forces to reject it in the WTO (Aryeetey et al. 2021).

The call for patent waivers and sharing of property rights for COVID-19 vaccines do not have the support of the pharmaceutical industry and wealthy countries, which prefer donating doses by way of charity through vaccine-provision schemes such as COVAX, the global initiative set up by the WHO that ensures equitable access to new COVID-19 vaccines for at best $20 \%$ of the population in poorer countries (Bassi 2021). Although COVAX has often been praised in the media for its effort to promote just distribution for vaccines, its public representation is said to be more of a hype than a reality. Sariola (2021:2) claims that COVAX as a global initiative funded by various philanthropic funders and wealthy countries has not been able 'to remove global vaccine injustices and at worst reproduces differences between the haves and the have-nots with a seeming guise of "doing something about it"'. A genuine equitable vaccine distribution must consider the inequalities present among various populations. It demands that decision-making on access must be based on one of the recognised principles of bioethics, namely justice (Bolcato et al. 2021). Distributing vaccines through COVAX does not support suspension of patents or ownership for COVID-19 vaccines as public goods but maintains the current global vaccine inequality with poorer countries begging for extra doses from wealthy countries.

Donating millions of doses of COVID-19 vaccines does not promote justice to allow equitable access by all nations to the vaccines. It only reinforces the status quo. It implies that the US and wealthy countries would still be buying millions of doses using taxpayers' money at manufacturers' prices, allowing the top pharmaceutical companies to keep their patents and absolute ownership of their vaccines. It also implies paternalism, making poorer countries dependent on the alms of wealthier countries, rather than empowering the former to participate in the ownership and production of these vaccines as public health goods. It is from public knowledge and participation in research risks that the current COVID-19 vaccines were developed by scientists whose research studies are performed in public institutions, supported by private and public organisations, and financed largely by taxpayers' money (Navarro 2021). And apparently, the primary role of the pharmaceutical firms is only to commercialise these vaccines and roll them out to the market after being developed by scientists using public funds and approved by the Food and Drug Administration (FDA) for emergency use. If the public has participated so much in the COVID-19 vaccine development and funding, why should drug makers possess absolute property rights to the vaccines?

The social issue on how to address the global shortage of COVID-19 vaccines and loosen the absolute patent control of big pharmaceutical firms to the popular vaccines often focuses on their legal, logistical and technical aspects but sidelines the moral dimension. Specifically, analysing the moral justification of the current vaccine distribution set-up and absolute ownership of COVID-19 vaccines by top drug companies from the Catholic moral point of view, specifically from a set of moral principles of the Roman Catholic Church (RCC) called Catholic social teaching (CST), has been neglected by scholars and policymakers. There is a limited theological literature that uses CST principles to explain why distributive justice must first be established to provide greater access of the poor to COVID-19 vaccines as public goods before acts of charity by rich nations to address vaccine scarcity. Catholic social teaching teaches that an authentic Christian charity demands justice. Charity cannot be used as an excuse to maintain social inequality. As Pope Benedict XVI (2005) explains in his encyclical Caritas in Veritatis, charity can never be used as a façade by the rich to maintain an unjust status quo it created:

Works of charity - almsgiving - are in effect a way for the rich to shirk their obligation to work for justice and a means of soothing their consciences, while preserving their own status and robbing the poor of their rights. Instead of contributing through individual works of charity to maintaining the status quo, we need to build a just social order in which all receive their share of the world's goods and no longer have to depend on charity. (para. 26)

The morality of the big pharmaceutical companies' current control and ownership of vaccines, which are crucial and essential to put an end to the current COVID-19, has not been analysed carefully by Catholic moral theologians, although the RCC has developed a set of social doctrines called CST to guide Christians, policymakers, business firms and state authorities on how to establish a just and moral society. This article aims to explain why distributive justice must prevail over donation of excess vaccine doses in the global vaccine distribution system, claiming that these vaccines have communal character and should be treated as global public health goods under CST's moral principles on distributive justice, universal destination of earth's goods and the common good.

This article has two major parts. The first part briefly elaborates CST's moral doctrines on justice and charity, solidarity, subsidiarity, distributive justice, the universal destination of earth's goods and the common good as the article's theoretical foundation to morally justify the public good character of the COVID-19 vaccines. The second part scrutinises the absolute ownership of these vaccines by the big top drug makers and the morality of suspending patents rights in the light of CST's moral principles on social dimension of private ownership and distributive justice. It argues that the current COVID-19 vaccines are chiefly created 
by scientists and the public or people outside the pharmaceutical companies, developed in government institutions, and funded by government funds; thus, vaccine ownership must be shared by all nations as public health goods under the moral principle of distributive justice, universal destination of earth's goods and the common good. It calls for what Sariola (2021) calls the 'subversion of the intellectual property rights system' to ensure equal access of all nations, especially the poorer ones, to the much-needed COVID-19 vaccines. It contends that before the US and rich countries could donate extra doses to the poor, distributive justice must first be served by pressuring the WTO to suspend indefinitely or share the patent rights of top pharmaceutical companies over their COVID-19 vaccines to developing nations and declare these immunisations as part of global public health goods that must be available to all in the spirit of solidarity of all nations.

\section{Theoretical foundation Catholic social teaching on Christian charity and
justice}

Over the centuries, the RCC has developed a set of social doctrines called Catholic social teaching (CST) that guides believers and state authorities on how to form a society marked by peace, concord and justice towards all (Dulles 2002). Catholic social teaching:

[E]mbodies social principles and moral teaching that is articulated in the papal, conciliar and other official documents issued since the late nineteenth century and dealing with the economic, political and social order. (Kizito \& Juma 2015:1)

It serves as 'a set of principles for reflection, criteria for judgment and directives for action for all the members of the Church and society' (Gaudium et Spes [Joy and Hope] 1965: para. 23).

Two of the major social doctrines of the RCC are on charity and justice. For CST, it is always an obligation of all people and Christians to help those in misery. In the global arena, it implies that citizens of developed countries have a moral duty to share their wealth and resources and help poor people in least developed countries. However, helping others for CST requires respecting the human rights of all, giving what is due to everyone. The CST teaches that genuine charity demands justice in society, recognising and respecting the legitimate human rights of individuals and peoples (Caritas in Veritate [Charity in Truth] 2009: para.6). Doing justice and transforming the world is a constitutive dimension of the preaching of the Gospel for the RCC (Justice in the World; World Synod of Bishops 1971: para.6). Justice aims to build the earthly city according to law.

In relation to COVID-19 vaccine distribution, doing justice implies morally establishing first whether the popular vaccines are privately owned by the pharmaceutical companies or publicly owned by all nations as global public health goods. If by virtue of justice, the public owns the vaccines, then wealthy nations must first require the WTO to waive the patents of these vaccines and allow poorer nations to manufacture them locally. They must also demand in the United Nations (UN) that drug makers and private and public institutions must assist developing countries to manufacture the vaccines. Before sharing extra doses of the COVID-19 vaccines to poor nations as an act of charity, rich nations must first morally establish justice. The proper moral response to address the current global vaccine scarcity is not doling out extra doses by rich countries in the name of charity but providing low- and middle-income countries with property rights they rightly deserved in the name of justice. Phelan et al. (2020) argue that:

[M]ultilateral legal agreements could be the path back to global health security and justice by re-establishing norms of international solidarity, committing to global equitable vaccine access initiatives, and laying a foundation for a post-pandemic era built on multilateralism and cooperation. (p. 800)

For the RCC, there is no genuine charity without first establishing justice. Charity is the perfection of justice. It must not be used as a cover-up for an injustice:

[C]harity goes beyond justice, because to love is to give, to offer what is 'mine' to the other; but it never lacks justice, which prompts us to give the other what is 'his', what is due to him by reason of his being or his acting. I cannot 'give' what is mine to the other, without first giving him what pertains to him in justice. If we love others with charity, then first of all we are just towards them. Not only is justice not extraneous to charity, not only is it not an alternative or parallel path to charity: justice is inseparable from charity, and intrinsic to it. (Caritas in Veritate 2009: para. 6)

What connects justice, charity and the common good in society for CST are the moral principles of solidarity and subsidiarity. In today's pandemic, nations, rich and poor, must work together in solidarity and subsidiarity to overcome obstacles and attain unity to achieve global herd immunity. For the Catholic Church, the principle of solidarity must be seen above all in its value as a moral virtue that determines the order of institutions.

Solidarity is an authentic moral virtue, not a:

[F]eeling of vague compassion or shallow distress at the misfortunes of so many people, both near and far. On the contrary, it is a firm and persevering determination to commit oneself to the common good. That is to say to the good of all and of each individual because we are all really responsible for all. (Pontifical Council for Justice and Peace 2005: para. 193)

On the one hand, the principle of solidarity requires that men and women today must cultivate a greater awareness that they are debtors of the society of which they have become part:

$[T]$ hey are debtors because of those conditions that make human existence liveable, and because of the indivisible and indispensable legacy constituted by culture, scientific and technical knowledge, material and immaterial goods and by all that the human condition has produced. (Pontifical Council for Justice and Peace 2005: para. 195) 
The principle of subsidiarity, on the other hand, requires that:

A community of a higher order should not interfere in the internal life of a community of a lower order, depriving the latter of its functions, but rather should support it in case of need and help to coordinate its activity with the activities of the rest of society, always with a view to the common good. (Catechism of the Catholic Church 1993: para. 1883)

For the RCC, it is impossible to promote the dignity of the person, especially during the current pandemic, without showing concern for the family, groups, associations and local territorial realities of society (Pontifical Council for Justice and Peace 2005:185).

\section{Catholic social teaching and distributive justice}

Justice is generally understood as giving what is due to the other. For CST and other moral traditions, there are basically three basic types, namely: commutative justice, social justice and distributive justice. Commutative justice is a type of justice that requires fairness in all types of contracts between individuals or private social groups. Social justice requires that persons who have obligations to be active and productive in the life of society and society must enable them to participate in this way. But distributive justice requires that the allocation of income, wealth and power in society must be evaluated in light of its effects on persons whose basic material needs are unmet (United States Catholic Bishops 1986: paras. 68-71).

For CST, distributive justice deals with inequalities of wealth under the free-enterprise system of economics. It is anchored on the RCC's moral principle called the universal destination of earth's goods, which states that earth is created by God for the entire humanity and not to specific individuals or groups; thus, all people or nations must have equal ownership of it (Kilchrist \& Block 2006:102). In CST tradition, private ownership is a basic human right, but it has moral limits. Pope Pius XI (1931), for instance, stressed the balance between the right to own private property and the social dimension of property ownership in his social encyclical Quadragesimo Anno [In the 40th Year]. Catholic social teaching always emphasises the moral obligation attached to the right to private property. Andolsen (2008) argues:

$[T]$ he trajectory in Catholic social thought increasingly stresses that private property is legitimate to the extent that it is used in ways that promote human dignity and autonomy and that are consistent with the common good. (p. 71)

Private ownership is only a social mortgage and subordinated to the principle of the common good, which is defined by CST as the sum total of social conditions which allow people, either as groups or as individuals, to reach their fulfillment more fully and more easily' (Gaudium et Spes 1965: para. 26). If the common good of all in society is affected, private owners have the moral obligation to share their property to others, especially to the poor in the name of distributive justice. This is implied in India and South Africa's request for patent waivers at the WTO, emphasising the public character of the COVID-19 vaccines as public goods which must be shared to all people and countries to enable them to reproduce the vaccines swiftly at affordable prices.

With the global cooperation and sharing of resources and WHO's ACT Accelarator, COVID-19 vaccines were developed and rolled out in the market in less than 12 months. This simply indicates communal sharing of resources for pharmaceutical research, which allowed companies to access the vast creative, intellectual and technological resources required to tackle the formidable challenge of turning the riches of the genome into a treasure trove of new treatments' (Munos \& Chin 2009:1). This global sharing has loosened 'the entrenched distinctions and separations demarcating "public" and "private," "commercial" and "notfor-profit," and "North" and "South," in order to usher in a new kind of "open" science' (Lezaun \& Montgomery 2015:10). The primary role of the Big Pharma is only to commercialise the developed vaccines which are largely created by scientists of various nationalities using public funds and tested by voluntary participation of various countries in WHO's solidarity trials.

Currently, Big Pharma still enjoys absolute property rights to the popular vaccines with patent rights to produce, sell or distribute them as they please. Under the Trade Related Aspects of Intellectual Property Rights Agreement (TRIPs) by WTO, drug makers who own intellectual property hold exclusive rights to their medical products without competing generic products in the market. 'This way, they are able to keep a foothold of the markets and the prices high with little competition over similar products' (Sariola 2021:1). TRIPs provide the pharmaceutical industry absolute rights to their invention and innovation. Thus, manufacturers have absolute control of their vaccines under the patent system of the WTO. Patent law grants them 'the right to make, use, sell, offer for sale, or import a patented invention for the term of the patent' (Sun 2021:151).

This absolute ownership by the big pharmaceutical companies to their medical products proved to be the most serious obstacle faced by poorer nations to reproduce or manufacture the patented vaccines locally. More than onethird of the world's population has no access to essential drugs and more than half of this group lives in the poorest regions of Africa and Asia (Sterckx 2010). And the current patent system blocks the access of the poor nations to essential medicines and the current COVID-19 vaccines. The intellectual property rights (IPRs) are crucial obstacle for global vaccine access. Instead of making vaccines available openly, IPRs protect industry profits over human health and well-being (Sariola 2021).

Allowing the drug makers to control the distribution of publicly funded COVID-19 vaccines is a serious violation of distributive justice as it results in the deprivation of access to poor countries. Distributive justice demands equitable distribution of economic goods and services in society (ed. Lamont 2016). A closer analysis on the ownership of the 
current vaccines reveals that the drug makers do not completely own and finance the development and production processes of their vaccines. They are developed by people outside the pharmaceutical companies and funded largely by government funds. Thus, they must be considered communally owned by humanity as public health goods. Even if the pharmaceutical companies have the legal title to their vaccines, CST's moral principle on distributive justice and the universal destination of earth's goods mandate drug makers to give up their absolute property rights as the global common good has already affected with the millions of people dead.

\section{COVID-19 vaccines as public health goods}

The idea that COVID-19 vaccines are public health goods started in the:

[W]orld Health Assembly (WHA) in May, 2020 when current and former politicians and civil society leaders from around the world that included the President of Ghana, Nana Akufo-Addo, the Prime Minister of Pakistan, Imran Khan, and the President of South Africa and Chair of the African Union, Cyril Ramaphosa, called for a 'bold international agreement' that guarantees global equitable access to vaccines as global public goods.... (Phelan et al. 2020:800)

Dhai (2021) describes a global public health good as:

[A] good whose impacts are equitably spread across the globe without causing division. The benefits of these goods cannot be priced, and hence the principle of exclusion cannot be applied to these goods. The use of such goods by one individual cannot be allowed to reduce their availability to others. The good and its benefits must be available at negligible or zero cost to all in the global village, hence they are not marketable. (p. 2)

The concept of global public health good in relation to COVID-19 vaccines did not prosper in the WHA at the WHO. Despite the initiative of top leaders from developing countries, the only resolution adopted during the WHA was the recognition of immunisation, rather than vaccines themselves, as a global public good. And after this assembly, 'the global legal landscape has shifted from a rhetoric of global public goods to a reality largely based on vaccine nationalism' (Phelan et al. 2020:800). Developed countries hoarded the vaccines using bilateral agreements with drug makers to protect their own citizens. They used the law called Advance Purchase Agreements (APAs) with vaccine manufacturers, to pre-order and hoard vaccines for 2021, resulting in scarcity of vaccines for low- and middle-income countries (Phelan et al. 2020).

In today's pandemic, vaccines are essential health goods for the survival of humanity, especially for the poor. Before rich countries led by the US aim to donate COVID-19 vaccines to poorer countries, they must first examine the ownership of these vaccines, whether they should be considered privately owned goods for profit or publicly owned global public health goods for all people. The CST fully supports the individuals and groups' ownership of goods and services that they privately produced and financed but not when the public is chiefly involved in the development and funding of essential vaccines for humanity's survival. In this case, the ownership assumes a communal character. The current initiative to develop COVID-19 vaccines involves a variety of private and public groups and organisations, as well as a cooperation of developed and developing nations in scientific research and solidarity clinical trials spearheaded by the WHO to test the efficacy of these vaccines and administer them to all people to attain global herd immunity.

'Indeed, vaccine research and development, manufacturing, and delivery typically involves a long, deliberate process that takes a decade or more' (Bloom et al. 2021:410). Developing and producing the present COVID-19 vaccines in such a short time to contain the coronavirus could have been a long, tedious and unaffordable task without the contribution of scientists, public research institutions, government support and public funding. 'COVID-19 vaccine development has been facilitated by private-to-private sharing of vaccine technologies, clinical development capacity, vaccine production techniques and facilities, and experience' (Bloom et al. 2021:412). Yet, 'communities of color (i.e. Black, Latinx, and Indigenous communities), who remain at highest risk for infection, have been peripheral, not central actors in the pursuit of COVID-19 vaccines' (Ojikutu et al. 2021:366). This only implies a form of injustice, showing social discrimination and racism: that despite the fact that non-Caucasian volunteers from developing countries had participated actively in clinical trials and exposed to health hazards during vaccine development, they were still not given priority to access the COVID-19 vaccines.

Countries which want the COVID-19 vaccines as public goods or people's vaccines cite public investment in vaccine development as a moral justification to sharing of property rights and waiving of patent protections. The US, for instance, has committed over 10 billion dollars (via Operation Warp Speed) with the aim of delivering 300 million doses of a safe and effective vaccines by January 2021 (U.S. Department of Health \& Human Services 2020). This has reached up to:

[ $\$ 18$ billion, including $\$ 6$ billion reallocated from the national COVID-19 stockpile and $\$ 1$ billion reallocated from the Centers for Disease Control and Prevention (CDC) and originally intended to support state and local health authorities. (Bloom et al. 2021:411)

The EU president also acceded that Europe invested billions to help develop the world's first COVID-19 vaccines (Thambisetty 2021:2). This implies that billions of dollars of taxpayers' money are spent to develop the current vaccines and requires the participation of thousands of volunteers from developing countries who usually received only the placebo rather than the vaccine itself to test the effectivity of immunisation, exposing them to great dangers, which is thus unethical and exploitative (Ahmad \& Dhrolia 2021). Even though Big Pharma did not totally fund and perform the entire vaccine production, it disregards the participation of developing countries in clinical trials and their human 
contribution in producing these vaccines. What adds to this injustice is the fact that Big Pharma prioritises the US, UK, Germany and other rich countries which hoarded the supply of these vaccines, allowing them to pre-order the supply through a law called Advanced Purchase Agreement (APA), ignoring the contribution of developing nations to the vaccine development and their willingness to pay the price. The global injustice and artificial shortage of COVID-19 vaccines in the world (Ahmad \& Dhrolia 2021; Navarro 2021) are created by rich nations that have bought in advance these vaccines at the expense of low- and middle-income countries. The APAs that resulted in vaccine nationalism may be legal but highly immoral and contrary to CST's moral principle on solidarity and distributive justice.

Contrary to popular belief, the patent holders of COVID-19 vaccines did not fully develop and fund all the components of their products when the FDA gave them emergency use authorisation (Bloom et al. 2021):

$[D]$ edication of significant human resources to the research behind COVID-19 vaccine development has also been the key. As of early September 2020, 321 vaccine candidates were in development, with 33 in clinical trials involving 280000 test subjects across 470 sites in 34 countries. (p. 412)

That includes low- and middle-income countries through solidarity trials (Bloom et al. 2021:412). Cooperation of various people also plays a key role in vaccine development and distribution (Bloom et al. 2021). The participation of thousands of people in clinical trials and cooperation among researchers and policymakers have made the development and production of the present vaccines a reality.

Moreover, the components of COVID-19 vaccines are obtained in government institutions with public funding.

Developing vaccines is always a difficult and time-consuming process because they are meant for people who have not yet manifested disease symptoms. Usually, it takes around 17 years for a vaccine to complete, from medical research to hospital use (Hanney et al. 2020). But this did not happen in the production of the current vaccines against the COVID-19 pandemic with public assistance and funding. To accelerate the development of COVID-19 vaccines, the Coalition for Epidemic Preparedness Innovations (CEPI) estimated that the cost is at least $\$ 2$ bn (CEPI 2020), which is largely shouldered by governments and/or philanthropic organisations. Justice requires then that the public must own and control these vaccines as public health goods and not the pharmaceutical companies. As already mentioned, billions of US dollars are already spent by the US and developed countries to expedite the development of the COVID-19 vaccines and the non-monetary help in terms of participation in clinical trials and raw materials were contributed by developing countries, making the vaccine development a truly global effort.
Apart from utilising private and public funding for vaccine research and development, big pharmaceutical companies also utilise the network support from multilateral institutions such as the World Bank to expedite financial transactions. The CEPI, for instance, that supports vaccine development is supported by a World Bank financial intermediary fund to enable it to bring together public, philanthropic and private funding to respond to global priorities. Through this fund, CEPI can act as a global mechanism for funding vaccine development until vaccines can be licenced or used under emergency use provisions (Yamey et al. 2020:1405). The pharmaceutical firms benefit from the global network of multilateral institutions to produce their COVID-10 vaccines.

Governments of rich countries also aided vaccine manufacturers to expedite their vaccine development and production. In the US, for instance, the primary role of vaccine manufacturers is to execute the clinical or process development and manufacturing plans, while the US government through its Operation Warp Speed (OWS) takes care of the technical, logistic or financial hurdles. Operation Warp Speed is a partner of the US Department of Health and Human Services (HHS), the Department of Defense (DOD) and the private sector to advance the development, manufacturing and distribution of vaccines by providing 'support to promising candidates and enabling the expeditious, parallel execution of the necessary steps toward approval or authorization of safe products by the Food and Drug Administration (FDA)' (Slaoui \& Hepburn 2020:1701). Thus, it appears that the big pharmaceutical companies which hold the ownership and patents provided little investment and participation for the development of these vaccines. Big Pharma has been uninterested to invest in vaccines for decades because they know that it is less profitable. Vaccines can only be used once or twice unlike medicines that people take every day. It only became interested when the US relief programme doled out to them $\$ 22$ bn (Burleigh 2021) with the right to patent these vaccines. With this huge amount that greatly lower its expenses and production costs of these vaccines, the public through the federal government should have been the co-investor and co-owner (Krellenstein \& Morten 2020) and the vaccines should have been made as people's vaccines (The Lancet 2020).

Thus, it only took less than a year for pharmaceutical firms to finish their COVID-19 vaccines. A great feat indeed because it normally takes more than a decade to create new vaccines. This unusual speed could not have been achieved without the support of governments of rich countries led by the US and Germany, scientists, participants in clinical trials, and various private and public institutions helping the pharmaceutical companies to expedite the development of the COVID-19 vaccines. Low- and middle-income countries participated largely in the clinical trials of these vaccines through the WHO's solidarity trials, exposing their volunteers to possible serious negative effects or even deaths. They also provide raw materials and scientific input through their scientists through WHO's vaccine accelerator to develop these jabs, thus Big Pharma saved a lot of production cost. And yet, they were not 
given an equal chance to access these vaccines to promptly immunise their citizens (Dyer 2020). Through advanced purchase agreements, the developed countries led by the US, Canada and the UK have been allowed by Big Pharma to hoard and pre-order the vaccine supply (Su et al. 2021). The entire production process of these vaccines involved various actors, agencies and processes, both private and public, which are largely outside the pharmaceutical companies before they are commercialised and sold in the market.

Navarro (2021) claims that the development of the most essential part in the production of the most successful vaccines (Pfizer and Moderna) has been done with public funds, in public institutions, in rich countries (especially, in the US and Germany)'. Scientists, public institutions, philanthropic organisations and governments have exerted a lot of effort and spent public money to realise these vaccines. And yet, the ownership and patents of these COVID-19 vaccines are exclusively awarded to the pharmaceutical companies as private goods instead of being public goods to make them accessible to all.

Catholic social teaching teaches that private ownership is a social mortgage and has moral limits. If the common good is already affected, private property must turn into public goods. For CST, the right to private property is not absolute and is subordinated to the moral principle called the universal destination of earth's goods. Private ownership has a social dimension. It is a social mortgage and subordinated to the principle of the common good. Pope Leo XIII reminded the wealthy property owners on their binding moral obligation to share their monetary surplus with those in need: 'Man should not consider his material possessions as his own, but as common to all, so as to share them without hesitation when others are in need' (Rerum Novarum 1891: para. 2). Pope Pius XI (1931) also stressed to put a balance between the individual right to private property and the social dimension of property in the encyclical Quadragesimo Anno [In the Fortieth Year]. And John Paul II (1991) in his encyclical Centesimus Annus [100 years] further stressed the social dimension of private ownership under the moral principle on the universal destination of earth's goods. Catholic social teaching always emphasises the moral obligations attached to the right to private property: The trend in Catholic social thought is recognising the legitimacy of private ownership if utilised to promote human dignity, autonomy and the common good (Andolsen 2008):

$[T]$ he drug companies' exclusive control over their drug formulas and processes are a social grant, not an innate right. The TRIPs agreement is a social policy that may legitimately be subject to social scrutiny and social ethical limits, not an expression of the drug companies' unquestionable, primordial moral rights. (p. 83)

Sariola (2021:2) has made a compelling argument why the IPR of the COVID-19 vaccines by the drug companies must be subverted to become global public goods:

$[A]$ rguments to defend IPRs simply do not hold. The commonly presented claim that IPRs protect innovator companies from market failure and financial risks does not apply in case of
COVID-19 vaccines because the research was done predominantly on public funding from various governments in the Global North, which means that companies had to invest very little, and there continues to be an enormous market for vaccines. COVID-19 vaccines should be treated as global public goods because at present, the protections of IPRs to the vaccine companies are causing health and socioeconomic suffering globally, rather than alleviating them. (p. 2)

Ownership patents give owners the right to exclude others from using the product, reduce competitive supply and increase prices. With intellectual monopoly capitalism, the quest to be competitive in global markets has led to economic concentration, oligopolies and a reduction in competition (Sell 2020). Thus, the shortage of vaccines and millions of deaths in today's pandemic is primarily caused by patents that guarantee the patent holder monopoly in the production and distribution of their vaccines. Although there are other factors that hinder an equitable global distribution of vaccines such as vaccine hesitancy and low acceptance even in low- and middle-income countries (Solis Arce et al. 2021), hoarding of vaccine supply by developed countries (Dryer 2020; Navarro 2021), developing countries' lack of infrastructure for transfer of knowledge and massive investment for vaccine manufacturing (Maxmen 2021), as well as corruption and favouritism in vaccine roll-out (Rahman 2021), monopoly of COVID-19 vaccines through patents is still the primary barrier. As Navarro (2021) contends, it is:

[T] he intellectual property, guaranteed by the state and by the laws of international trade and its agents, is what creates an artificial 'shortage' of vaccines, which generates astronomical profits at the cost of not having enough vaccines to alleviate the serious consequences of the pandemic and prevent the death of millions of people. (p. 2)

Krellenstein and Morten (2020) argue that because essential medicines for COVID-19 received huge amount of grants and state subsidies, assistance from government scientists and voluntary public participation in clinical trials before they are rolled out to the market, government must be made co-inventors and co-patent holders of these pharmacological products to expand global access and lower the price. The IPR monopoly of the big pharmaceutical companies to their vaccines, which are crucial for the survival of all people against the pandemic, is the fundamental cause of vaccine scarcity, inequality and global injustice. Some scholars, such Gonsalves and Yamey (2021), claim that a suspension of the IPRS of Big Pharma alone will not solve the shortage of COVID-19 vaccines. But they also conceded that this is a crucial step towards wider global access, making them people's vaccines. As Maxmen (2021) explains, suspending patents controlled by Big Pharma is only one of the three major obstacles to make vaccines available to developing countries, which also include the (1) transfer of knowledge and (2) massive investment. But suspending patent rights as requested by South Africa and India is the first crucial step to a wider distribution of these vaccines. As Thambisetty (2021) claims: 
Once the invention is created, the patent in effect generates an artificial scarcity, allowing the value of the vaccine to be maintained, managed and even increased. The scarcity feeds on under-investment in capacity-building and reluctance to transfer technology and manufacturing know-how...It allows the patent holder to orchestrate the manufacture of the product through restrictive licencing. (p. 1)

Thus, the IPR system of the WTO blocks vaccine access of poor countries and legitimises the pharmaceutical industry to make exclusive decisions for their vaccines (Sariola 2021:1).

\section{Conclusion}

This article has shown that justice must first be established before charity and donation by rich countries can genuinely be done. Catholic social teaching teaches that authentic Christian charity demands justice. In the case of the COVID-19 distribution system, CST's moral principle on distributive justice must first be served before rich nations donate millions of doses to poorer country as an act of charity. Distributive justice requires sharing of ownership and suspension of patents of the drug makers' vaccines to allow poor and developing countries to reproduce them to protect the global common good and save the lives of the poor. Distributive justice is based on CST's moral principles on the universal destination of earth's goods and the common good. A close assessment of the ownership of the current COVID-19 vaccines revealed that the pharmaceutical companies did not totally develop and finance the vaccine development. Cooperation of various people and public funding allowed the fast development of the vaccines. The pharmaceutical companies' main contribution is only in the commercialisation and rolling out of the vaccines in the market. Thus, the vaccines have a communal dimension and must be considered as global public health goods. Following CST's doctrine that private ownership has moral limits and social dimension, patent waivers requested by India and South Africa in the WTO are morally justified not just temporarily but indefinitely. Instead of donating vaccines to address the current vaccine scarcity, the US and wealthy countries must pressure the WTO and top drug makers to share their property rights and patents to their vaccines to protect the common good and attain a just and moral vaccine distribution system.

\section{Acknowledgements Competing interests}

The author declares that he has no financial or personal relationships that may have inappropriately influenced him in writing this article.

\section{Author's contributions}

V.O.B. is the sole author of this article.

\section{Ethical considerations}

This article followed all ethical standards for research without direct contact with human or animal subjects.

\section{Funding information}

This research received no specific grant from any funding agency in the public, commercial or not-for-profit sectors.

\section{Data availability}

Data sharing is not applicable to this article as no new data were created or analysed in this study.

\section{Disclaimer}

The views and opinions expressed in this article are those of the author and do not necessarily reflect the official policy or position of any affiliated agency of the author.

\section{References}

Ahmad, A. \& Dhrolia, M.F., 2021, 'No to placebo-controlled trials of Covid-19 vaccines' Indian Journal of Medical Ethics VI(2), 1-7. https://doi.org/10.20529/ IJME.2021.019

Andolsen, B., 2008, 'Essential goods for AIDS widows: Property, including intellectual property, in Catholic social teaching', Journal of the Society of Christian Ethics 28(1), 67-86. https://doi.org/10.5840/jsce200828127

Aryeetey, E., Engebretsen E., Gornitzka Å., Maassen P. \& Stølen S., 2021, 'A step backwards in the fight against global vaccine inequaties', The Lancet 397(10268), 23-24. https://doi.org/10.1016/S0140-6736(20)32596-4

Bassi, L., 2021, 'Allocating COVID-19 vaccines globally: An urgent need', JAMA Health Forum 2(2), e210105. https://doi.org/10.1001/jamahealthforum.2021.0105

BBC News, 2021, 'US to buy 500 million Covid vaccine doses for world', BBC News, 09 June 2021, viewed from https://www.bbc.com/news/world-us-canada-57416519.

Bloom, D.E., Cadarette, D., Ferranna, M., Hyer, R.N. \& Tortorice, D.L., 2021, 'How new models of vaccine development for COVID-19 have helped address an epic public health crisis', Health Affairs 40(3), 410-418. https://doi.org/10.1377/ hlthaff.2020.02012

Bolcato, M., Rodriguez, D., Feola, A., Di Mizio, G., Bonsignore, A., Ciliberti, R. et al., 2021, 'COVID-19 pandemic and equal access to vaccines', Vaccines 9(6), 538 https://doi.org/10.3390/vaccines9060538

Burleigh, N., 2021, 'How the COVID-19 vaccine injected billions into Big Pharma - And made its executives very rich', Forbes, viewed 25 July 2021, from https://www. forbes.com/sites/forbesdigitalcovers/2021/05/14/virus-book-excerpt-ninaburleigh-how-the-covid-19-vaccine-injected-billions-into-big-pharma-albertbourla-moncef-slaoui/?sh=17ed81557d80.

Caritas in Veritate [Charity in Truth], 2009, Encyclical of Pope Benedict XVI on integral human development in charity and truth, Libreria Editrice Vaticana, Vatican, viewed 04 June 2021, from https://www.vatican.va/content/benedict-xvi/ en/encyclicals/documents/hf_ben-xvi_enc_20090629_caritas-in-veritate.html.

Catechism of the Catholic Church, 1993, Catechism of the Catholic Church, Libreria Editrice Vaticana, Citta del Vaticano, viewed 15 May 2021, https://www.vatican. va/archive/ENG0015/_INDEX.HTM.

Coalition for Epidemic Preparedness Innovations (CEPI), 2020, '\$2 billion required to develop a vaccine against the COVID-19 virus', CEPI Latest News, 13 March 2020, viewed from https://cepi.net/news/.

Cueni, T., 2020, 'The risk in suspending vaccine patent rules', The New York Times, 10 December 2020, viewed from https://www.nytimes.com/2020/12/10/ opinion/coronavirus-vaccine-patents.html.

Dhai, A., 2021, 'Access to COVID-19 vaccines as a global public good: A co-ordinated global response based on equality, justice and solidarity is key', South African Journal of Bioethics and Law 14(1), 2-3. https://doi.org/10.7196/SAJBL.2021. v14i1.768

Dryer, O., 2020, 'Covid-19: Many poor countries will see almost no vaccine next year, aid groups warn', BMJ: British Medical Journal 371, m4809. https://doi. org/10.1136/bmj.m4809

Dulles, A.S.J., 2002, 'Catholic social teaching and American legal perspectives', Fordham Urban Law Journal 30(2002), 277-289, viewed 30 June 2021, from https://ir.lawnet.fordham.edu/cgi/viewcontent.cgi?article=1859\&context=ulj.

Dyer, O., 2020, 'COVID-19: Many poor countries will see almost no vaccine next year, aid groups warn', BMJ 371:m4809. httpd://doi.org/10.1136/bmj.m4809

Gaudium et Spes [Joy and Hope], 1965, Pastoral constitution on the church in the modern world, Vatican Archive, Vatican, viewed 01 July 2021, from https://www. vatican.va/archive/hist_councils/ii_vatican_council/documents/vat-ii const_19651207_gaudium-et-spes_en.html.

Gonsalves, G. \& Yamey, G., 2021, 'The COVID-19 vaccine patent waiver: A crucial step towards a "people's vaccine"', BMJ 373, n1249. https://doi.org/10.1136/bmj. n1249

Hanney, S.R., Wooding S., Sussex J. \& Grant J., 2020, 'From COVID-19 research to vaccine application: Why might it take 17 months not 17 years and what are the wider lessons?', Health Response Policy System 18, 61. 
Irwin, A., 2021, 'What it will take to vaccinate the world against COVID-19?', Nature, 25 March 2021, viewed 20 July 2021, from https://www.nature.com/articles/ d41586-021-00727-3.

John Paul II, 1991, Centesimus Annus [100 Years], Libreria Editrice Vaticana. viewed 06 June 2021, from https://www.vatican.va/content/john-paul-ii/en/encyclicals/ documents/hf_jp-ii_enc_01051991_centesimus-annus.html.

Kilchrist, E. \& Block, W., 2006, 'Distributive justice', International of Social Economics 33(1/2), 102-110. https://doi.org/10.1108/03068290610642201

Kizito, O. \& Juma, F., 2015, 'Catholic social justice principles: An African philosophical response', Arts and Social Sciences Journal 6(2), 1-7. https://doi.org/10.4172/ 2151-6200.1000107

Krellenstein, J. \& Morten, C., 2020, 'The U.S. government's apparent co-ownership of patents protecting Remdesivir', 20 May 2020, from https://ssrn.com/ abstract $=3880720$

Labonte, R. \& Johri, M., 2020, 'COVID-19 drugs and vaccine patents are putting profit before people', The Conversation, viewed 01 June 2021, from https:// theconversation.com/covid-19-drug-and-vaccine-patents-are-putting-profittheconversation.com/cor

Lamont, J. (ed.), 2016, Distributive justice, Routledge, Oxon.

Lezaun, J. \& Montgomery, C.M., 2015, 'The pharmaceutical commons: sharing and exclusion in global health drug development', Science, Technology, \& Human Values 40(1), 3-29. https://doi.org/10.1177/0162243914542349

Maxmen, A., 2021, 'In shock move, US backs waiving patents on COVID vaccines: The development from the Biden administration draws cheers from public-health researchers and ire from drugmakers', Nature, viewed 20 July 2021, from https:// www.nature.com/articles/d41586-021-01224-3.

Munos, B. \& Chin, W., 2009, 'A call for sharing: Adapting pharmaceutical research to new realities', Science Transnational Medicine 1(9). https://doi.org/10.1126/ scitransImed.3000155

Navarro, V., 2021, How neoliberal dogma has prolonged the COVID-19 pandemic, LSE Phelan US Centre, viewed 15 July 2021, from https://blogs.Ise.ac.uk/ usappblog/2021/03/25/how-neoliberal-dogma-has-prolonged-the-covid-19pandemic/.

Ojikutu, B., Stephenson, K.E., Mayer, K.H. \& Emmons, K.M., 2021, 'Building trust in COVID-19 vaccines and beyond through authentic community investment', American Journal of Public Health 111(3), 366-368. https://doi.org/10.2105/ AJPH.2020.306087

Phelan, A.L., Rourke, M., Maleche, A. \& Wang, C., 2020, 'Legal agreements: Barriers and enablers to global equitable COVID-19 vaccine access', The Lancet 396(10254), and enablers to global equitable COVID-19 vaccine access', The

PhRMA, 2021, 'PhRMA statement on WTO TRIPS intellectual property waiver', viewed 30 July 2021, from https://www.phrma.org/Press-Release/PhRMA-Statement-onWTO-TRIPS-Intellectual-Property-Waiver.

Pontifical Council for Justice and Peace, 2005, Compendium of Social Doctrine of the Church, Libreria Editrice Vaticana, viewed 28 May 2021, from http://www.vatican. va/roman_curia/pontifical_councils/justpeace/documents/rc_pc_justpeace doc 20060526 compendio-dott-soc_en.html.

Pope Benedict XVI, 2005, Deus Caritas Est [God is Love], Libreria Editrice Vaticana, Vatican, viewed 05 June 2021, from https://www.vatican.va/content/benedict-xvi/ en/encyclicals/documents/hf_ben-xvi_enc_20051225_deus-caritas-est.html.

Pope Pius XI, 1931, Quadragesimo Anno [The Fortieth Year], Libreria Editrice Vaticana, viewed 30 May 2021, https://www.vatican.va/content/pius-xi/en/encyclicals/ documents/hf_p-xi_enc_19310515_quadragesimo-anno.html.
Quadragesimo Anno [On the Fortieth Year], 1935, Encyclical of Pope Pius XI on reconstruction of the social order, Libreria Editrice Vaticana, Vatican, viewed 30 May 2021, from https://www.vatican.va/content/pius-xi/en/encyclicals/ 30 May 2021, from https://www.vatican.va/content/pius-xi/
documents/hf_p-xi_enc_19310515_quadragesimo-anno.html.

Rahman, K., 2021, 'Mitigating corruption risks in COVID-19 vaccine rollout: What can donors do?', U4 Helpdesk Answer, 07 April 2021, viewed 17 July 2021, from https://www.u4.no/publications/mitigating-corruption-risks-in-covid-19-vaccinerollout.pdf.

Rerum Novarum [Labor and Capital], 1891, Encyclical of Pope Leo XIII on labor and capital Libreria Editrice Vaticana, Vatican viewed 25 May 2021, from from https://www.vatican.va/content/leo-xiii/en/encyclicals/documents/hf_I-xiii_ enc_15051891_rerum-novarum.html.

Sariola, S., 2021, 'Intellectual property rights need to be subverted to ensure global vaccine access', BMJ Global Health 6, e005656. https://doi.org/10.1136/ bmjgh-2021-005656

Sell, S.K., 2020, 'What COVID-19 reveals about twenty-first century capitalism: Adversity and opportunity', Development 63, 150-156. https://doi.org/10.1057/ s41301-020-00263-z

Slaoui, M. \& Hepburn, M., 2020, 'Perspective: Developing safe and effective Covid vaccines - Operation warp speed's strategy and approach', The New England Journal of Medicine 382(21), 1969-1973. https://doi.org/10.1056/NEJMp2005630

Solis Arce, J.S., Warren, S.S., Meriggi, N.F., Scacco, A., McMurry, N., Voors, M. et al., 2021, 'COVID-19 vaccine acceptance and hesitancy in low- and middle-income countries', Nature Medicine 27, 1385-1394. https://doi.org/10.1038/s41591021-01454-y

Sterckx, S., 2010, 'Patents and access to drugs in developing countries: An ethical analysis', Developing World Bioethics 4(1), 58-75. https://doi.org/10.1111/ j.1471-8731.2004.00067.x

Su, Z., McDonnell, D., Cheshmehzangi, A., Li X., Maestro, D., Šegalo, S. et al., 2021 'With great hopes come great expectations: Access and adoption issues associated with COVID-19 vaccines', JMIR Public Health Surveillance 7(8), e26111. https:// with COVID-19 vaccines',
doi.org/10.2196/26111

Sun, H., 2021, 'Patent responsibility', Stanford Journal of Civil Rights and Civil Liberties 17(141), forthcoming, viewed 05 June 2021, from https://ssrn.com/ $17(141)$, forthcomin
abstract $=3846452$.

Thambisetty, S., 2021, Vaccines and patents: How self-interest and artificial scarcity weaken human solidarity, British Politics and Policy at LSE (2021), 2, viewed 20 July 2021, from https://blogs. Ise.ac.uk/politicsandpolicy/vaccines-and-patents/.

The Lancet, 2020, 'Global governance for COVID-19 vaccines', Lancet (London, England) 395(10241), 1883. https://doi.org/10.1016/S0140-6736(20)31405-7

United States Catholic Bishops, 1986, Economic justice for all: Pastoral letter on Catholic social teaching and the U.S. economy, Confraternity of Christian Doctrine, Washington, DC, viewed 24 May 2021, from https://www.usccb.org/upload/ economic_justice_for_all.pdf.

U.S. Department of Health \& Human Services, 2020, Fact sheet: Explaining operation warp speed, viewed 07 June 2021, from https://www.hhs.gov/about/ news/2020/06/16/fact-sheet-explaining-operation-warp-speed.html.

World Synod of Bishops, 1971, Justice in the world, viewed 25 June 2021, from https:// www.cctwincities.org/wp-content/uploads/2015/10/Justicia-in-Mundo.pdf.

Yamey, G., Schafehoff, M., Hatchett, R., Pate, M., Zhao, F. \& Kennedy, K.M., 2020, 'Ensuring global access to COVID-19 vaccines', The Lancet 395(10234), 1405-1406. https://doi.org/10.1016/S0140-6735(20)30763-7 